Without over-generalising it can be said that resources and materials in addition to activities pertaining to the resources wholly within a particular Federal or State territory would be within the power of the government of that territory. This includes the environment and all matters pertaining to land, water (not supplies, services or distribution), Malay reservation, local government and administration (except in Federal Territories) including forestry, mining and agriculture. Matters pertaining to administration of information, survey, trade, industry, shipping, communication, transport, infrastructure (as long as it is federal works), industries, health and education among others would fall within the ambit of the Federal government legislative (Article 74) and executive jurisdiction (Article 80 ). There are instances, where the jurisdiction and mandates are concurrently shared such as protection of wild animals and birds, national parks, town and country planning, public health and sanitation, drainage and irrigation.

The Constitution does not provide a clear definition on what is meant by development, but does mention conservation in the context of a development plan in Article 92. The said Article actually provides a platform for the Federal government to publish and put into operation a development plan in one or more areas in one or more States. In this Article, "development plan" means a plan for the development, improvement, or conservation of the natural resources of a development area, the exploitation of such resources, or the increase of means of employment in the area. What is interesting to note here, is that the Federal government in pursuit of national interest can proclaim a whole area as a development area, which in this case, an area reserved for the purposes of conservation of natural resources within the context of development.

As Langkawi islands sit cusped within the state of Kedah, it is bound by the legislative and executive purview of the state; in as far as land is concerned. The Laws of the Constitution of Kedah 1959 ("Kedah Constitution 1959") states that the executive authority of the State rests with the Ruler of the State, and exercisable by him or the State Executive Council or Menteri Besar (Chief Minister), and the Legislative Assembly may confer executive functions on other persons as well (Article 34).

Referring to the Constitution, executive authority rests with the Ruler, who can refer the said powers to the State Executive Council or Menteri Besar, and the legislative powers over matters set out in the Constitution rests with the Kedah State Legislative Assembly, which passes enactments for gazettal, upon approval of the Ruler. The earlier mentioned research identified more than 120 statutory instruments both Federal and State that have bearing on matters, either directly or indirectly, on Langkawi Geopark. This article will not even attempt to sift and discuss all the instruments identified, but instead will focus on the aspects identified in the earlier discussions on building blocks with specific focus on land use planning. 


\section{BUILDING BLOCKS, KEY LAND USE RELATED STATUTES AND LANGKAWI GEOPARK}

Taking a standpoint grounded in land use planning, the link between law and land use planning as noted by Needham (2007), Moroni (2007a, 2007b) and Booth (2007) can be divided into several types, i.e.: when it is used to either directly intervene in the way someone uses his or her land, either through prohibitive measures, or permit based measures, or restrictive measures or remedial measures; and indirectly, through means of influencing the use of the land, such as providing infrastructures or facilities. Focusing on the earlier discussed building blocks from the perspective of conservation and development, land use planning can serve as powerful means to seek to recognise boundaries, set out 'controls' to facilitate conservation and 'guide' development, advocate sustainable tourism and economic development as well as ensure heritage is protected, conserved and serve as means to educate and inculcate a sense of place. This section will look at specific selected Federal statutes which special emphasis on land, land use and planning only.

\section{Designation of Boundary or Area}

The term land is interpreted in the National Land Code 1965 ("NLC 1965")(Section 5) as including the surface of the earth and all substances forming that surface; the earth below the surface and all substances therein; all vegetation and all natural products, whether or not requiring periodical application of labour to their production, and whether on or below the surface; all things attached to the earth or permanently fastened to any thing attached to the earth, whether on or below the surface; and land covered by water. It would seem that this include what can be termed as geodiversity, i.e. the natural range of geological and soil features and aspects related to biodiversity when the terms 'all things attached' are read broadly.

For land situated within the jurisdiction of a State, Section 40 of the NLC 1965 provides that property to lands within the territories of a State and all minerals and rocks lies with the State Authority (Section 5 interpret this to mean Ruler or Governor), including all matters related to disposal (Sections 41 to 50). Land above the shoreline is classified into three types (Section 51), i.e. town land, village land and country land. Categories for land use are as set out in Section 52, i.e. agriculture, building and industry, and this is specified in a gazette that also spells out conditions requiring its use for a particular purpose. Implied conditions for alienated agriculture land (Section 115) includes maintenance and cultivation according to good husbandry rules, no building shall be erected unless it is for the purpose of dwelling for the proprietor or purposes related to agriculture. Regarding alienated lands categorised for buildings, conditions can be set for various purposes, 
such as residential, commercial, administrative or for purposes of providing educational facilities or recreation (Section 116).

It is important to note that the State Authority also has the right of use or access to alienated land (Section 57), which could include carrying out or laying or removing drains, sewers, pipes, cables or wires. With regard to boundary setting, an option lies with the power of the State Authority to reserve any land for public purpose (Section 62), by gazetting the same and describing the purpose. However, the State Authority can revoke the reservation. As far as boundary setting the NLC 1965 can be useful for purposes of reserving areas that have been identified as heritage sites or areas to be used for educational purposes (in this case for demonstration of geological heritage sites and scientific research areas).

Another option for setting the boundary lies with the Town and Country Planning Act 1976 (TCPA 1976), which adopts the interpretation of land as that in NLC 1965 with an additional inclusion of any estate or interest in, or right over, land (Section 2). The TCPA 1976 provides the platform to effect conservation, use and development of all lands within a territory of a State (Section 4) and to an extent even areas between two states or more (Section 6A). Section 7 provides the means of establishing a boundary in that a survey can be undertaken to establish the limits of the area to be subjected to a land use plan, taking into review the principal physical, economic, environmental and social characteristics including principal land uses of the area. The boundary so determined can be delineated in either a structure plan (Section 8), a local plan (Section 12) or special area plan (Section 16B). The setting of the boundary in either of the plans mentioned would then set the perimeter in which measures to regulate and control land uses will be instituted.

\section{Designation of Authority}

From the perspective of land use planning, there are two operating considerations; that there are legal provisions to mandate an authority to regulate matters pertaining to land use planning or legal provisions that enable the execution of authority through a partnership arrangement. It is clear in respect of land, in this case Langkawi, the authority over land rests with the State Authority pursuant to Section 40 of the NLC 1965.

For land use planning, the TCPA 1976 becomes the point of reference. The term 'authority' here perhaps can be read to mean the responsibility and power to execute and undertake actions over a particular subject matter or activity. With regard to land use planning authority, in the state of Kedah, the authority rests with the State Planning Committee, in as far as it exercises its function to promote the conservation, use and development of all lands in the State; regulate, control, plan and coordinate all development activities 
in the State; advise the State Government on matters relating to conservation, use and development of land in the State; and assist in the collection, maintenance and publication of statistics (Section 4, TCPA 1976). The Committee may also give local planning authorities directions; and cause local inquiry or hearing (Section 4). The principal advisor the Committee is the State Director of Town and Country Planning (Section 4), who is also responsible for carrying out decisions and implementing policies set by the Committee.

At the local level, the local authority serves as the local planning authority, unless an area is deemed not forming part of an area under a local authority, then the State Director of Town and Country Planning serves as the local planning authority (Section 5). This local planning authority holds great powers (Section 6) in that it can regulate, control and plan the use of land and buildings within its area, in addition to collecting, maintaining and publishing statistics. The authority to make rules pursuant to the TCPA 1976, rests with the State Authority (Section 58), which can include the regulation of the development of land in accordance with proper planning; classes of use of land and buildings; control of density, be it plot ratio or use of land; regulation of height, design, appearance and siting of buildings, set backs and open spaces; protection of ancient monuments and lands of historical and architectural interests; the details of the forms and content or a structure plan and local plan and the procedure to be followed in the preparation, submission and approval as well as the qualification of persons submitting such plans. It is perhaps from this provision, as well as the provisions of the Ministerial Functions Act 1969, that a one stop centre is established to aid the consolidation of various assessments, evaluation and remedial aspects for land use, ensuring that decisions and interventions made by the local planning authority are informed. It is important to note here that geoparks, its existence and sustainability are highly dependent on how the land where the area designated as a geopark sits is use and planned for use. In this respect the State Planning Committee and the local planning authority play a pivotal role in ensuring that all aspects of geopark conservation and development (as suggested in Table 1) are considered and taken into account when decisions and interventions are made with regard to land use planning.

\section{Sustainable Tourism and Sustainable Economic Development}

Taking off from the sustainable economic development standpoint, from a land use planning perspective, much would rest on how the economic activities are planned to suit local conditions and infrastructure support. It is however influenced by the policies that determine and direct the trends for economic development, and in Langkawi, the duty free status and tourism destination has been the primary economic driver. This is evident by the establishment of the Langkawi Development Authority, under the Lembaga Pembangunan Langkawi Act 1990, to promote, stimulate and undertake economic and social development in the Kawasan Lembaga Pembangunan Langkawi 
(Langkawi Development Authority Area hereinafter referred to as "LDAA") as a tourist destination and duty free area, subject of course to two factors, that they consult the State Government and that the activities are confined within the LDAA (Section 4 of the LPLA 1990). Kawasan Lembaga Pembangunan Langkawi is stated in Section 9, as areas notified in a Gazette with the concurrence of the State Government, within which the Lembaga Pembangunan Langkawi shall perform its functions.

The same Section 4 also provides for the promotion of tourism and infrastructure as well as residential, agricultural, industrial and commercial development, but confined again to the determined development area. It can (Section 4) carry out activities related to tourism; even research and training; initiative preliminary studies of possible development and redevelopment areas; act on behalf or carry out activities on behalf of the Federal and State Governments; provide assistance to any public authority including financial assistance, subject to approval; require government departments or agencies carrying out activities within the LDAA to submit reports of their activities; impose fees or charges it deems fit to give effect to any of its functions; and regulate, coordinate and undertake development in the LDAA. It important to note, in as far as the LDAA is concerned, that the Lembaga Pembangunan Langkawi holds the mandate to carry out its function, but the exercise of the same beyond the LDAA is unclear.

The TCPA 1976 however, provides a wider ambit, as it can set out the planning directions particularly in relation to land use planning that can support sustainable economic development and tourism, through either the incorporation of key aspects, factors and points for consideration when developing or conserving an area, at the structure plan, local plan and special area plan stage. This can be read from Sections 8 (structure plans), 12 (local plans) and 16B (special area plan) of the TCPA 1976, as discussed earlier, which takes into consideration the current policies in respect of social and economic planning and development as well as environmental protection of the State and nation as a whole. The development of the plans pursuant to Sections 8,12 and 16B are done with consultations with public, and draft plans are published to facilitate views. In the preparation of local plans (Section 12) the considerations are even more extensive, with plans taking into account factors such as the protection and improvement of the physical environment; preservation of natural topography; improvement of landscape; preservation and planting of trees; open spaces; preservation and enhancement of character and appearance of buildings.

It would seem that the TCPA 1976, can serve as an ideal vehicle to capture all the necessary inputs prior to developing or regulating the development and conservation of land, focusing on the key needs to boost sustainable economic development and tourism. Besides highlighting the key factors and aspects to be considered and factored, the TCPA 1976 also takes into account the public consultation procedure to improve and revise a 
draft to ensure that benefits and trade offs can be better addressed either through direct intervention of control, restriction and regulation or through the provision of planned infrastructure support to foster sustainable economic development and tourism.

\section{Conservation of Geological, Biological and Cultural Heritage}

Regarding the conservation of geological, biological and cultural heritage, the TCPA 1976, through Sections 8, 12 and 16B provides a wonderful backdrop to expand the factors for consideration as proposed in Table 1. For example, Section 35A can be invoked to ensure that when it appears to the local planning authority, it is expedient in the interest of amenity to preserve any tree, trees or group of trees in its area, it may make a tree preservation order with respect to such tree, trees or group, which can seek the prohibition of felling subject to permission or securing of planting of trees in replacement. However, more importantly, Section 16B should be considered, where a special proposal can be made for the designation of a special area for special and detailed treatment by development, redevelopment, improvement, conservation or management practice, or partly by one and partly by another method, of the whole or part of such special area, and the nature of the treatment proposed. This is crucial, as it can perhaps be used to influence areas where land has been alienated to structure measures that will help facilitate conservation. This is something that requires further exploration, and would require specific directives from the State Authority, leveraging on the authority of the State Authority under section 57 of the NLC 1965 to have access and use over alienated lands. This is one way to be explored apart from outright acquisition of land alienated under the Land Acquisition Act 1960 (revised 1992).

The National Forestry Act 1984 (NFA) also provides an avenue for the protection of all three components, as a blanket that wraps the bands of protection over materials and specimens within the forests itself. This has been put to practice in Langkawi, where geological heritage does draw some protection from the NFA 1984 for example under Section 81 that sets out acts that are prohibited in protected forests. As for biological heritage it can draw comfort from having specific areas classified as permanent forest reserves for purposes such as forest sanctuary for wildlife, amenity forest, education forest or research forest (this would to an extent help fulfil the component on geoparks and education).

\section{CONCLUSION}

All in all, land and its use is the critical factor in geopark conservation and development.. The selected statutes discussed above, indicate that it is possible to use the land use planning regulative mechanism to effect provisions that will ensure geoparks are conserved and developed sustainably. The role that can be played by the TCPA 1976 is 
pivotal, as it set the tone or set the point for intervention in as far as land use planning is concerned, particularly in setting out measures to facilitate geopark friendly review, evaluation, assessment, rehabilitation and remediation processes and procedures.

Initial steps can be taken to re-look at how processes and procedures can be reframed to incorporate the components, aspects and factors that make up a geopark, its conservation and development. As large areas of Langkawi has been alienated to private ownership, the drawing of a boundary that gazettes the area as geopark reserves under the NLC 1965 may not be feasible, save certain areas under the control of the State Authority. Instead, what can be done is that the boundary be incorporated in either the state structure or local plan, to indicate which planning controls will come into effect for the area. In addition for identified heritage sites, Section 16B can serve to set out the planning measures to ensure that such sites can be better protected, conserved and properly developed without compromising the heritage value and integrity.

\section{ACKNOWLEDGEMENTS}

This paper has been made possible with feedbacks and interactions with researchers from groups that were funded from the following grants: UKM-GUP-PLW-08-11-048, UKMAP-PLW-01-2009, UKM-OUP-PLW-10-46/2011 and UKM-OUP-PLW-11-49/2011. The grants facilitated field works to be conducted in Langkawi for gathering research materials.

\section{REFERENCES}

Booth, P. 2007. The Control of Discretion: Planning and the Common Law Tradition. Planning Theory, 6, 127-145. Sage Publications.

Burek, C.V. and Prosser, C.D. 2008. The History of Geoconservation: An Introduction. In The History of Geosconservation. Burek C.V. and Prosser, C.D., eds. Geological Society, London Special Publications .

Chan K. L. Geraldine, Sarah Aziz, Halimaton Saadiah Hashim and Rahimah Abdul Aziz. 2010. Sistem Jaringan Governans untuk Langkawi Geopark: Pengkisahan Konseptual (trans. Governance Networks for Langkawi Geopark: A Conceptual Framework). Akademika, 80 Sept-Dis, 69-84.

Chiras, D. D. and Reganold, J. P. 2005. Natural Resource Conservation (9th Edition). New Jersey. Pearson Prentice Hall.

Daniels, T. and Lapping, M. 2005. Land Preservation: An Essential Ingredient in Smart Growth. Journal of Planning Literature, 19, 316-329. 
Eder, W. E. and Patzak, M. 2004. Geoparks - Geological Attractions: A Tool for Public Education, Recreation and Sustainable Economic Development. Episodes, 27(3), 162-164.

Gray, M. 2008. Geodiversity: The Origin and Evolution of a Paradigm. In The History of Geosconservation. Burek C.V. and Prosser, C.D., eds. Geological Society, London Special Publications 300. 31-36.

Hart, H. L. 1994. The Concept of Law. Cane, P., Honore, T., and Stapleton, J., eds. New York: Oxford University Press.

Halimaton Saadiah Hashim, Rahimah Abdul Aziz, Sarah Aziz and Chan K. L. Geraldine. 2010. Governans untuk Geopark: Langkawi sebagai Acuan (Geopark Governance: Langkawi as a Model). Akademika, 80, Sept-Dec, 39-54.

Ibrahim Komoo. 2004. Geoheritage Conservation and Its Potential for Geopark Development in Asia-Oceania. In Warisan Geologi Malaysia (trans. Geological Heritage of Malaysia), Mohd Shafeea Leman and Ibrahim Komoo, eds. Bangi: LESTARI, UKM.

Jokilehto, J. 1990. Definition of Cultural Heritage: References to Documents in History. Prepared for the ICCROM Working Group 'Heritage and Society'. Accessed at: http://cif.icomos.org/pdf_docs/Documents\%20on\%20line/Heritage\%20definitions. pdf (last accessed 10th October 2011).

Jordan, C. F. 1995. Conservation Replacing Quantity with Quality as a Goal for Global Management. Canada: John Wiley and Sons.

Martin, D. G., Scherr, A. W. and City, C. 2009. Making Law, Making Place: Lawyers and the Production of Space. Prog Human Geogr, 34, 175-192.

McKeever, P. J. 2009. The UNESCO Global Network of National Geoparks: Geological Heritage and Sustainability. LESTARI Public Lecture Series No. 7. Bangi: LESTARI, UKM.

McKeever, P. J. and Zouros, N. 2005. Geoparks: Celebrating Earth Heritage, Sustaining Local Communities. Episodes, 28(4), 274-278.

Millennium Ecosystems Assessment. 2005. Ecosystems and Human Well-Being: Biodiversity Synthesis. Washington, D.C.: World Resources Institute.

Ministry of Science, Environment and Technology. 1998. National Policy on Biological Diversity Malaysia. Government of Malaysia, 1998.

Moroni, S. 2010. Rethinking the Theory and Practice of Land Use Regulation: Towards Nomocracy. Planning Theory, 9(2), 137-155. Sage Publications.

Moroni, S. 2007(a). Introduction: Land Use, Planning and the Law. Planning Theory, 6, 107-111. Sage Publications.

Moroni, S. 2007(b). Planning, Liberty and the Rule of Law. Planning Theory 6(2), 146163. Sage Publications.

Morrison, W. 1997. Jurisprudence: From the Greeks to Post-Modernism. Cavendish Publishing Limited. 4,5 and 231 
Needham, B. 2007. Final Comment: Land-Use Planning and the Law. Planning Theory, 6(2), 183-189.

Pinchot, G. 1967. The Fight for Conservation. Seattle: University of Washington Press (originally published in 1910).

Sarah Aziz and Ibrahim Komoo. 2002. A Legal Basis for Geological Heritage Conservation. In Geological Heritage of Malaysia: Geoheritage Mapping and Geosite Characterisation, Ibrahim Komoo and Mohd Shafeea Leman, eds. LESTARI UKM. Pages110-117.

Sharina Abdul Halim, Ibrahim Komoo, Hood Salleh and Mustaffa Omar. 2011. The Geopark as a Potential Tool for Alleviating Community Marginality: A Case Study of Langkawi Geopark, Malaysia. Shima: The International Journal of Research Into Island Cultures, 5(1), 94-113.

Sharples, C. 1995. Geoconservation in Forest Management: Principles and Procedures. Tasforests, 7 December, 37-50.

Sharples, C. 1993. A Methodology for the Identification of Significant Landforms and Geological Sites for Geoconservation Purposes. Forestry Commission, Tasmania.

Singh, G.P. 2004. Principles of Statutory Interpretation (9th ed.). India: Wadhwa and Company Nagpur.

Starkweather, S., Low, A. and Pearlmen, K. 2004. Managing Growth: Recent Legal Literature. Journal of Planning Literature, 18, 267-308

Susong, H. and Pearlmen, K. 2000. Regulating Beauty: A Review of Recent Law Journal Literature. Journal of Planning Literature, 14, 637-662

United Nations Environmental Programme and World Tourism Organisation. 2005. Making Tourism More Sustainable: A Guide for Policy Makers. http://www.unep.fr/ shared/publications/pdf/DTIx0592xPA-TourismPolicyEN.pdf (10 October 2011).

UNESCO. 2010. Guidelines and Criteria for National Geoparks seeking UNESCO's assistance to join Global Geoparks Network (GGN) (April 2010). http://www. globalgeopark.org/english/AboutGGN/dcmt/201010/P020101022558665601621. pdf (30 April 2011).

Wilson, E.O., 1988. The Current State of Biological Diversity. In Biodiversity, Wilson E.O and Peter F.M., eds., 3-18. Washington, D.C.: National Academy Press.

World Commission on Environment and Development (WCED). 1987. Our Common Future. New York: Oxford University Press, 1987. 
Laws referred:

Federal Constitution of Malaysia 1957

Interpretation Act No. 23 of 1967

Land Acquisition Act 1960 (revised 1992)

Lembaga Pembangunan Langkawi Act 1990

National Forestry Act 1984

National Land Code 1965

Town and Country Planning Act 1976 


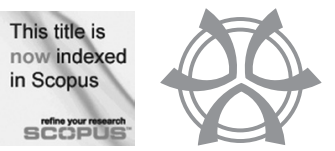

\title{
POTENTIAL BIOSITES OF SIGNIFICANT IMPORTANCE IN LANGKAWI GEOPARK: TERRESTRIAL VERTEBRATE FAUNA
}

\author{
Norhayati, A. ${ }^{1,2}$, Chan, K.O. ${ }^{3}$, Daicus, B. ${ }^{2,4}$, Samat, A. ${ }^{1}$, Grismer, L.L ${ }^{2,5}$, and \\ Mohd Izzuddin, A. ${ }^{2}$
}

\begin{abstract}
Langkawi Geopark was bestowed the status of a global geopark by the Global Geoparks Network (GGN) and endorsed by the UNESCO as the 52nd member of the GGN in 2007, making it the first in Malaysia and South East Asia to be given the status. The status is due to its many unique and significant geological, biological, and cultural features in Langkawi. There are four types of geoheritage conservation mechanism in Langkawi Geopark, namely geosites, geological monuments, landscapes of scenic beauty and Geoforest Parks. These proposed geoheritage conservation mechanisms are being implemented at various stages from planning to establishment and monitoring. So far, 97 geosites have been identified in Langkawi Geopark, but there has not been any biosite identified, even though Langkawi Geopark is known for the high biodiversity of flora and fauna, many of which are endemic and rare. This article highlights nine potential biosites for biological conservation in Langkawi Geopark. These biosites are identified based on the presence of rare and endemic species and/or based on type locality, which is the original location where the species was found and described. The nine biosites are Gunung Raya, Wat Wanaram, Lubuk Semilang, Telaga Tujuh, Pulau Singa Besar, Sungai Kilim/Kisap, Sg. Temurun, Gua Kelawar, and Teluk Datai. Each biosite is accompanied by description of the area, species, threats, conservation values, and potential for development and conservation measures. Although only nine biosites are identified so far, this number is bound to increase in future when more sites for the biologically important flora, invertebrate fauna and marine flora and fauna groups are included.
\end{abstract}

\footnotetext{
${ }^{1}$ Associate Professor, Faculty of Science and Technology, UniversitiKebangsaan Malaysia, 43600 UKM Bangi, Selangor, Malaysia. E-mail: noryati@ukm.my

${ }^{2}$ Institute for Environment and Development (LESTARI), UniversitiKebangsaan Malaysia, 43600 Bangi, Selangor, Malaysia

${ }^{3}$ Department of Ecology and Evolutionary Biology and Natural History Museum and Biodiversity Institute, University of Kansas, Dyche Hall 345 Jayhawk Blvd, Lawrence, KS 66045, US

${ }^{4}$ Institute of Biological Sciences, Faculty of Science, University of Malaya, 50603 Kuala Lumpur, Malaysia

${ }^{5}$ Department of Biology, La Sierra University, 4500 Riverwalk Parkway, Riverside,, California, 92515-8247 USA
} 
Keywords: Biosites, biological conservation, biodiversity, Langkawi Geopark

\section{INTRODUCTION}

The Langkawi Archipelago is a cluster of 99 tropical islands in the northwestern Peninsular Malaysia. The archipelago covers an area of approximately $47.84 \mathrm{~km}^{2}$, located between the latitudes $6^{\circ} 10^{\prime} \mathrm{N}$ to $6^{\circ} 30^{\prime} \mathrm{N}$ and longitudes $99^{\circ} 35^{\prime} \mathrm{E}$ to $100^{\circ} \mathrm{E}$. Its islands range in size from $0.01-328 \mathrm{~km}^{2}$ and for the most part, are covered by primary forests. The largest of these islands, Pulau Langkawi $\left(328 \mathrm{~km}^{2}\right)$, is also the most environmentally diverse. Its interior is mountainous and covered with mixed dipterocarp forest and its highest peak, Gunung Raya, reaches $881 \mathrm{~m}$ above sea level. Its second highest peak, Gunung Machincang, reaches $701 \mathrm{~m}$ and is one of the oldest geological formations in Southeast Asia (Jones 1981; Stauffer and Mantajit 1981). Broad, flat, low-lying expanses fringe the interior mountains providing suitable relief for agricultural areas, as well as lowland dipterocarp forest, coastal vegetation, and mangrove communities.

On June 2007, Langkawi Island was accorded by the GGN and endorsed by the UNESCO as the $52^{\text {nd }}$ member of the Global Geopark Network, the first member in South East Asia to be given the status. Such an accomplishment can be basically attributed to the many unique and significant geological features, such as the oldest rock formation and the most complete sequence of Paleozoic to Mesozoic sedimentary formation in Malaysia, which represents the early history of the formation of the Malay Peninsula (Komoo et al. 2001). Langkawi Geopark falls under the jurisdiction of many government agencies by virtue of its multi-facet features which fall under the respective responsible bodies. However, Langkawi Development Authority (LADA) under the Ministry of Finance Malaysia has been given the task of a coordinator for the care, control and management of Langkawi Geopark, offshore islands and coral reefs.

In Langkawi Geopark there are four types of identification for geoconservation: namely geosites, geological monuments, landscapes of scenic beauty, and Geoforest Parks (Komoo 1999). Efforts to conserve these geoheritage units are at various stages of implementation from identification to site/material description, and monitoring. A geosite is a potential protected site which contains one or several geological or landscape features of outstanding heritage value. The status of a protected area to some of these geosites will be determined after more detailed studies. Currently, there are 97 geosites in Langkawi Geopark. A geological monument (GM) is an area or site which represents a single geological or landscape system of outstanding heritage value, such as Pulau Ular GM, Pulau Singa Kechil GM, and Pulau Langgun GM. A landscape of scenic beauty is an area of aesthetic beauty that has geologically important features (Tanot 2011). A Geoforest Park (GFP) is a protected area of nature conservation in which both biological 
and geological resources within the forest reserves are conserved hand in hand in order to promote integrated nature conservation and sustainable ecotourism (Shaharuddin et al. 2004). Three Geoforest Parks were established in 2005 under the jurisdiction of the Kedah State Forestry Department (Shaharuddin et al. 2005). These three Geoforest Parks are the Machincang Cambrian GFP, Kilim Karst GFP, and the Dayang Bunting Marble GFP.

The geopark definition by GGN (2010) includes the protection, conservation, management and promotion for tourism products not only of geo heritage but also of biological and cultural heritage types. However, since the establishment of Langkawi Geopark in 2007, no biosite has been identified, even though Langkawi is rich in biodiversity, many of which are endemic. A biosite is a physical area of land or water containing biological assets with particular attributes, such as the presence of rare or threatened flora, fauna or habitat required for their survival and/or rare or threatened vegetation communities (DSE 2005).

The rich biodiversity of Langkawi Geopark supports a high level of endemic and significant species and communities. Due to their isolated geographic locations, small sizes of surrounding islands, and limited access, there are a number of identifiable and common threats to biodiversity that need to be addressed. A number of terrestrial species and ecological communities occurring on Langkawi Geopark are listed as Critically Endangered, Endangered, or Vulnerable under the IUCN (2011) Red List Data or Protected or Totally Protected under the Wildlife Conservation Act 2010. This article highlights the profile of the unique terrestrial vertebrate fauna of Langkawi Geopark for identification of potential biosites of significant heritage value as part of the conservation entities in Langkawi Geopark. The profiling encompasses threats and management actions relevant to the Langkawi Geopark's overall biodiversity, with emphasis on rare and significant species and communities of Langkawi Geopark. This approach would enable a more holistic and cost-effective management of Langkawi Geopark's biodiversity. The aim of this project is to continue the inventory and database of biosites in Langkawi Geopark to fill the information gap in the knowledge regarding the location of high conservation value areas. This knowledge would then be able to provide strategic guidance for the managers and administrators, planners, enforcement officers, communities and tourists for future investment in biodiversity conservation in Langkawi Geopark. This knowledge would also enable all key land managers and stakeholders to improve protection and management of these biosites.

\section{OVERVIEW OF SPECIES: VERTEBRATE FAUNA}

Studies on vertebrate animals in Langkawi have had a long history since the early 1900s. The earliest known report on avifauna in Langkawi was in 1910 (Robinson and Kloss, 
1910). Most of the works were concentrated on four main islands: the main island of Pulau Langkawi, Pulau Singa Besar, Pulau Dayang Bunting and Pulau Tuba. The rest of the archipelago until now remains relatively untouched and unexplored. Thus, the potential for research for new discoveries of flora and fauna is huge. This article discusses the four main groups of fauna, namely fish, birds, herpetofauna, and mammals. A brief summary of the works done on each group is given below.

\section{Fish}

A number of stream fish collections were conducted in Pulau Langkawi by Tweedie (1936), Alfred (1969) and most recently by Amirrudin and Lim (2006). There was no particular report regarding the stream fishes of Pulau Langkawi between the years 1969 and 2006 except as part of a limnological survey by $\mathrm{Ng}$ and Ping (1989). Forty one fish species are presently known from the stream waters of the island (Amirrudin and Lim 2006) whereby 24 species are primary freshwater fishes. Thirty species were recorded for the first time in Pulau Langkawi, of which two species (Oreochormis mossambicus and Trichogaster pectoralis) were introduced. Anguilla marmorata, Acanthocobitis zonalternans and Dermogenys sumatrana were the three species recorded for the first time in Peninsular Malaysia (Izzati and Samat 2010).

\section{Birds}

The earliest known works on avifauna of Pulau Langkawi were by Robinson and Kloss (1910, 1911), followed by Robinson (1917), and Wells (1974). Local researchers came into the scene in the early 1980's by Siti Hawa (1984), Jeyarajasingan et al. (1999), Noramly (1998), Shukor et al. (2005). The most comprehensive compilation of the avifauna was by Yeap et al. (2005) who listed bird species recorded in Pulau Langkawi from the earlier researchers back to the 1900's. A total of 221 species from 58 families was generated. The total number of bird species in Langkawi is 238 species, which is about $32 \%$ of the total bird species in Peninsular Malaysia (Yeap 2005).

\section{Herpeto Fauna}

Out of the total 104 islands in the Langkawi Archipelago, only three islands - Pulau Langkawi, Pulau Tuba, and Pulau Singa Besar - have been surveyed for amphibians and reptiles (Ibrahim et al. 2006; Grismer et al. 2006; Grismer 2008; Grismer and Norhayati 2009; Lim et al. 2010; Norhayati et al. 2007; Zimmerer 2004). There are a total of 106 species of herpetofauna from the latest checklist in Langkawi (Lim et al. 2010). This total comprises 26 species of amphibians, 6 species of chelonids, 9 species of agamid lizards, 1 species of butterfly lizard, 10 species of geckoes, 8 species of skinks, 2 species of varanid lizards, and 44 species of snakes. Since that checklist, three new species of 
geckoes have been discovered and described: Cyrtodactylus macrotuberculatus (Grismer and Norhayati 2009), Cnemaspis monachorum (Grismer et al. 2009) and Cnemaspis roticanai (Grismer and Chan 2010), thus, increasing the total number of herpetofaunal species to 109. However, in comparison to the much smaller Seribuat Archipelago off the southeastern coast of Peninsular Malaysia, the Langkawi Archipelago is relatively low in its herpetological composition, having 15 times fewer species per area of landmass than the islands of the Seribuat Archipelago (Grismer and Norhayati 2009).

\section{Mammals}

Medway (1986) reported 16 species of terrestrial mammal species and 20 species of bats (Medway 1983) from Pulau Langkawi. The recent survey by Shukor et al. (2007) added three new records of murids and five new records of bats. For insectivorous bats, the total number from Pulau Langkawi is 21 species, which is comparably higher than those from Singapore (Yang et al. 1990) and Pulau Tioman (Medway 1966). The noteworthy species are the bats that roosts in all the caves, all three species of primates (Trachypithecus obscurus, Macaca fascicularis, Nycticebus coucang) and all the protected species listed in the Wildlife Conservation Act 2010.

\section{IDENTIFICATION OF POTENTIAL BIOSITES}

Nine potential biosites are identified so far, but this number is bound to increase in future when more sites for the biologically important flora, invertebrate fauna and marine flora and fauna groups are identified. The locations of the biosites are shown in Figure 1. Besides the physical description about each biosite, information about important species of fauna, status and potential threats found in each location are also provided.

\section{BIOSITE 1: GUNUNG RAYA}

Gunung Raya is the highest peak in Langkawi $(881 \mathrm{~m})$, with a clear $180 \mathrm{O}$ view over the island and even Thailand on a clear day. The road from the foothill leading to the peak is winding, and at the top is a watch tower, where the scenic landscape of the archipelago can be viewed for a small fee. The vegetation is primary hill dipterocarp forest. Gunung Raya is the type locality for two species of geckoes described below. Other than these two species, sightings of all the three hornbills in Langkawi, the Pouched Hornbills, Great Hornbill and the Oriental Pied hornbill are frequent here. Since there is only one resort at the peak, which caters for low volume tourists, there is not much threat for the native fauna there. The problem lies in the fact that many reptiles, especially pit-vipers found along the way to the peak are being collected frequently for trade, even though Gunung Raya is situated in a Forest Reserve. The good road access to the peak is the main reason for this. The authority could step up monitoring and enforcement along this road to curb these activities. 
Cnemaspis roticanai Grismer\& Chan 2010

Roticanai Rock Gecko/Cicak Batu Roti Canai (Appendix 1)

Cnemaspis roticanai is known only from the type of locality in the upper regions of Gunung Raya, Pulau Langkawi, Kedah, Malaysia (6²2’08.00”N; 9949’07.00” E). The natural vegetation where it occurs is primary hill dipterocarp forest on a steep hillside (Grismer and Chan 2010). This species has adapted to live on vegetation (leaves and tree trunks) as opposed to most of its other congeners which have a scansorial lifestyle.

\section{Cyrtodactylus macrotuberculatus Grismer \& Norhayati 2009 \\ Tuberculate Rock Gecko/Cicak Batu Tuberkul (Appendix 1)}

Cnemaspis macrotuberculatus was first described from Gunung Raya $\left(06^{\circ} 23.023 \mathrm{~N}\right.$, $99^{\circ} 49.126$ E; $621 \mathrm{~m}$ asl.; Grismer and Norhayati 2009). Since then, this scansorial species has been found in nearly all forested habitats ranging from sea level to the summit of Gunung Machincang at $700 \mathrm{~m}$. Specimens have been observed abroad only at night and have been found in karst formations, taking refuge in the rock cracks on Gunung Machincang, on granite boulders along water courses at Lubuk Semilang and Telaga Tujuh, crossing the road leading to the summit of Gunung Raya, beneath overpasses and on road cuts along this road.

\section{BIOSITE 2: KARST FORMATION AT WAT WANARAM}

Wat Wanaram is the location of a Buddhist temple with a karstic landscape setting as its background $\left(06^{\circ} 20.275 \mathrm{~N}, 99^{\circ} 52.507 \mathrm{E}\right.$; elevation $\left.35 \mathrm{~m}\right)$. The karstic landscape is characterised by the Setul Formation, which is the oldest carbonate rock in the Malay Peninsula and the neighbouring region (Scrivenor and Willbourn 1923). This OrdovicianDevonian rock comprises impure limestone, dolomitic limestone and two clastic members consisting of shale, highly silicous mudstone, siltstone and chert. According to Che et al. (2003), the rock formation forms a unique and fascinating morphology full of well preserved fossils exposed on rock surfaces, which are rarely found elsewhere in Peninsular Malaysia and should be considered as natural heritage. This site is also the type of locality for Cnemaspis monachorum, which have been found on the karst formations behind the temples. Besides that, Cyrtodactylus macrotuberculatus also occurs here together with $C$. pulchellus. Another important species found here is Trimerusurus venustus. Threats are considered low in this area due to low human contact since the site is under the care of the Buddhist monks. The limestone hills where the unique animals are found are frequented by Buddhist monks for meditation. Thus, this area is unlikely to be exploited by collectors/hunters. 
Cnemaspis monachorum Grismer, Norhayati, Chan, Daicus, Muin, Grismer \& Wood, 2008 - Monks Rock Gecko/Cicak Batu Sami (Appendix 1)

Cnemaspis monachorum is known only from the karst formation at WatWanaran, Pulau Langkawi, Kedah, Peninsular Malaysia (Grismer et al. 2009). Cnemaspis monachorum is a lowland, saxicolous species that appears to be restricted to the karst outcropping of WatWanaram near the town of Kuah in a region dominated by a mixture of primary coastal and lowland dipterocarp forest. Here, several specimens of this swift, agile, diminutive species were observed during the day along the periphery of the karst formation in broad view near the edges of cracks as well as on the surfaces of rocks in shaded areas.

\section{BIOSITE 3: LUBUK SEMILANG}

Lubuk Semilang Recreration Park is about $8 \mathrm{~km}$ from Kuah town and is located within the Gunung Raya Forest Reserve (06²1'50.02” N, 99 47’ 27.85” E; elevation 53m). The vegetation is primary lowland dipterocarp forest. There is a trail leading up to the peak of Gunung Raya known as the "Eagle Stair of a Thousand Memories" and also connects to Durian Perangin Recreation Park, which is about $10 \mathrm{~km}$ long. Among the rare species that occur here are the Large-headed frog (Limnonectes macrognathus) and the Yellow-eyed litter frog (Leptobrachium smithii). Threats to the fauna here are considered low since this area is within the jurisdiction of the Forestry Department as a Recreation Forest and illegal collection of animals is prohibited. However, the impact of tourists has put a toll on the environment due to the amount of rubbish that are not properly disposed. This might be the reason behind the outbreaks of Leptospirosis, which occurred here recently.

\section{Limnonectes macrognathus Boulenger 1917}

Large-headed frog/Katak Kepala Besar (Appendix 1)

Limnonectes macrognathus is distributed from Myanmar through northwestern and southern peninsular Thailand to Pulau Langkawi, Malaysia (Grismer et al. 2006). It can be considered as uncommon or seasonal because of the difficulty of finding it even in its known range in Langkawi. This is a predominantly Thai species that has found its way to Pulau Langkawi due to its close proximity with Thailand. It does not occur in Peninsular Malaysia and Pulau Langkawi appears to be the southernmost limit of its distribution.

\section{BIOSITE 4: TELAGA TUJUH}

Telaga Tujuh or the Seven Wells $\left(06^{\circ} 22^{\prime} 35.74\right.$ " N, $99^{\circ} 46^{\prime} 41.70^{\prime \prime}$ E; elevation $\left.39 \mathrm{~m}\right)$, is a well-known tourist site at Compartment 8 , Machincang Forest Reserve. It is about 20 $\mathrm{km}$ from Kuah town and is accessible by road. The vegetation here consists of lowland 
dipterocarp forest. The seven-step waterfall originates from Sg. Perangin at the peak of G. Machincang. This is one of the areas where Leptobrachium smithii occurs naturally. Since, this area is within a Forest Reserve, threats to the faunal life here are considered minimal.

Leptobrachium smithii Matsui, Nabhitabhata, and Panha, 1999

Smith's litter frog/Katak Serasah Daun Smith (Appendix 1)

Leptobrachium smithii is distributed from Southern Thailand and adjacent southern Myanmar; Sayaboury and Vientiane provinces, Laos; seemingly isolated population in Meghalaya, Assam, and Mizoram, India, and southeastern Bangladesh. In Malaysia, it is only found at Pulau Langkawi (Grismer et al. 2006). Prior to this, it is much confused with L. hasseltii (Berry 1975), but later on Iskandar (1998) and Matsui et al. (1999) suggested that true L. hasseltii was likely restricted to Java and adjacent islands. In addition to Telaga Tujuh, other localities where this species can be found are Sg. Sepetang $\left(06^{\circ} 22^{\prime}\right.$ 35.74” N, 9946'41.70” E; elevation 39m), Lubuk Semilang and Gunung Raya.

\section{BIOSITE 5: PULAU SINGA BESAR}

Pulau Singa Besar is a small island of approximately $11.3 \mathrm{~km} 2$ among the 99 islands in the Langkawi Archipelago, and is located off the northwest coast of the state of Kedah, Peninsular Malaysia. The work by Grismer (2008) reported a checklist of the herpetofauna of Pulau Singa Besar, totaling 12 species, comprising one frog, nine lizards, and two snakes. Lim et al. (2010) produced an updated checklist of the herpetofauna on Pulau Singa Besar, totalling 50 species. It is also the type locality for Sphenomorphus langkawiensis, described by Grismer (2008). Some parts of Pulau Singa Besar is a State land reserve area for public use and a part of the island is protected under the jurisdiction and management of the Department of Wildlife and National Parks. Thus, threats to the faunal life here are considered minimal.

\section{Sphenomorphus langkawiensis Grismer, 2008}

Langkawi Island forest skink/Mengkarung Hutan Pulau Langkawi (Appendix 1)

Sphenomorphus langkawiensis is known only from Pulau Singa Besar, reportedly found on the Cicada Trail. This trail starts with a small section of boardwalk proceeding along the sandy beach. It is about $2 \mathrm{~km}$ long. The trail is flanked on the left by disturbed forest and the right by the coast. This trail is popular among tourists from the main island during weekends and public holidays. This species, however, may occur throughout all forested areas on the island (Grismer 2011). 